\title{
Carcass Characteristics of Soviet Chinchilla Rabbits Supplemented with Vitamin C, E and Selenium during the Period of Heat Stress
}

\author{
S. Dinesh Kumar ${ }^{1 *}$, D. Anandha Prakash Singh ${ }^{1}$, A. Natarajan ${ }^{2}$ and K. Sivakumar ${ }^{1}$
}

Department of Livestock Production Management, Veterinary College and Research Institute, Namakkal, (TANUVAS), Tamil Nadu, India ${ }^{2}$ Animal Feed Analytical and Quality Assurance Laboratory, Namakkal, India

*Corresponding author

\section{A B S T R A C T}

\section{Keywords}

Broiler rabbits, Vitamin C, E and selenium, Carcass characteristics

Article Info

Accepted:

12 July 2018

Available Online:

10 August 2018
An experiment was conducted with 64 weaned Soviet Chinchilla rabbits of divided in to eight treatments consisting of eight animals in each treatment to find out the effect of vitamin $\mathrm{C}, \mathrm{E}$ and selenium in alone or combinations on their carcass characters during the period of heat stress. The dietary supplementation of vitamin $C\left(T_{2}\right)$ was given at the dose rate of (200mg per kg diet), vitamin $\mathrm{E}\left(\mathrm{T}_{3}\right)\left(40 \mathrm{mg}\right.$ per kg diet) and Selenium $\left(\mathrm{T}_{4}\right)(0.2 \mathrm{mg}$ per $\mathrm{kg}$ diet) and in combinations of $\mathrm{C}$ and $\mathrm{E}\left(\mathrm{T}_{5}\right)$ (200 and $40 \mathrm{mg}$ per $\mathrm{kg}$ diet), $\mathrm{C}$ and Selenium $\left(\mathrm{T}_{6}\right)\left(200\right.$ and $0.2 \mathrm{mg}$ per kg diet), E and selenium $\left(\mathrm{T}_{7}\right)(40$ and $0.2 \mathrm{mg}$ per $\mathrm{kg}$ diet) and Vitamin C, E and selenium ( $\left.\mathrm{T}_{8}\right)(200,40$ and $0.2 \mathrm{mg}$ per $\mathrm{kg}$ diet) respectively. This study was undertaken at the rabbit unit of Livestock Farm Complex, Veterinary College and Research Institute, Namakkal. Among the various supplementations vitamin $\mathrm{C}, \mathrm{E}$ and selenium combinations showed the highly significantly by $(\mathrm{P}<0.01)$ higher weight at slaughter $(2230.16 \pm 59.88)$, carcass weight $(1244.66 \pm 39.25)$ and dressing percentage $(55.80 \pm 0.71)$ but there was no significant difference noted in the weight of foreleg $(183.50 \pm 0.88)$, chest and back $(283.00 \pm 0.68)$, loin and flank $(285.00 \pm 0.51)$, pelt $(260.00 \pm 30.81)$ and hind leg $(383.00 \pm 2.08)$. The weight of edible offal's showed no significant difference in the carcass characters supplemented with vitamin $\mathrm{C}$, E and selenium during the period of heat stress.

\section{Introduction}

Rabbit farming is gaining popularity due to its high rate of reproduction, high genetic selection potential, rapid growth rate, early maturity, small body size, efficient feed utilization, high quality nutritious meat, and limited competition with humans for similar foods, and it also has great scope as it is relatively easy, rewarding, require low capital investment and takes little space compared to other livestock activities. The per capita consumption of meat in India is $5.0 \mathrm{~kg}$ as against the requirement of $12.40 \mathrm{~kg}$ per person per year with a deficit of $7.40 \mathrm{~kg}$ per person per year (Subramaniam Mohana Devi et al., 2014). Rabbit can convert 20 per cent of protein they eat into edible meat (Basavaraj et 
al., 2011) which is higher than pigs (16-18 per cent) and beef cattle (8-12 per cent). Though rabbit meat may not be able to bridge the requirement of protein demand of the population, its role as an alternate protein source is increasing. The present study deals with the carcass characteristics of Soviet Chinchilla rabbits supplemented with various antioxtants during heat stress period maintained in an organized farm.

\section{Materials and Methods}

At the end of the trial (16 weeks of age), six rabbits (3 males and 3 females) from each group, totaling forty eight rabbits, were selected randomly and slaughtered to evaluate the carcass characteristics. The study was undertaken at rabbit unit of Livestock Research Farm, Veterinary College and Research Institute, Namakkal. Slaughtering was done as per the method described by Ramayyan (1977). Standard statistical methodology was used to analysis the data (Snedecor and Cochran, 1994). The study included pre-slaughter weight, Hot carcass weight, weight of various parts like neck, foreleg, chest and back, lion and flank and hind leg; weight of various offals like head, lung and heart, G.I tract, liver, kidney, paw and tail, pelt and blood. Dressing percentage of rabbit without head was worked out as follows

Dressing percentage $($ without head $)=$

Carcass weight without head $(\mathrm{Kg})$

X 100

Live weight at slaughter $(\mathrm{Kg})$

\section{Results and Discussion}

\section{Carcass characteristics}

Pre-slaughter weight: The mean preslaughter weight of Soviet Chinchilla rabbits supplemented with various antioxidants are presented in Table 1.

The Soviet Chinchilla rabbits supplemented with vitamin $C$, vitamin $E$ and selenium $\left(T_{8}\right)$ recorded significantly $(\mathrm{P}<0.05)$ higher mean pre-slaughter weight $(2230.16 \pm 59.88 \mathrm{~g})$ when compared to all other treatments and the lowest (2019.33 $\pm 38.03 \mathrm{~g})$ pre-slaughter weight was recorded in the unsupplemented control $\left(\mathrm{T}_{1}\right)$ group.

\section{Hot carcass weight}

The mean hot carcass weight of Soviet Chinchilla rabbits supplemented with various antioxidants is presented in Table 1.

The vitamin $\mathrm{C}$, vitamin $\mathrm{E}$ and selenium $\left(\mathrm{T}_{8}\right)$ supplemented rabbits registered the highest $(1244.66 \pm 39.25 \mathrm{~g})$ mean hot carcass weight followed by vitamin $\mathrm{C}$ and $\mathrm{E}$ (1201.33 \pm $18.24 \mathrm{~g})$, vitamin $\mathrm{C}$ and selenium (1175.16 \pm $45.90 \mathrm{~g})$, vitamin C (1174.33 $\pm 24.57 \mathrm{~g})$, vitamin $\mathrm{E}(1141.66 \pm 27.35 \mathrm{~g})$, selenium $(1121.66 \pm 15.76 \mathrm{~g})$ and vitamin $\mathrm{E}$ and selenium $(1103.33 \pm 24.38 \mathrm{~g})$ supplemented rabbits. Among the groups, the unsupplemented control $\left(\mathrm{T}_{1}\right)$ rabbits had the lowest $(1055.66 \pm 20.54 \mathrm{~g})$ mean hot carcass weight.

The statistical analysis of mean hot carcass weight revealed highly significant $(\mathrm{P}<0.01)$ difference between the treatment groups.

\section{Dressing percentage}

The mean dressing percentage of Soviet Chinchilla rabbits supplemented with various antioxidants are presented in Table 1.

The Soviet Chinchilla rabbits supplemented with vitamin $C$, vitamin $E$ and selenium $\left(T_{8}\right)$ and vitamin $\mathrm{C}$ and $\mathrm{E}\left(\mathrm{T}_{5}\right)$ recorded the highest mean dressing percentage $(55.80 \pm 0.71$ and 
$55.80 \pm 0.67)$ followed by vitamin $\mathrm{C}(54.91 \pm$ 0.81 ), vitamin $C$ and selenium ( $54.82 \pm 1.01$ ), vitamin $\mathrm{E}(53.03 \pm 0.60)$, vitamin $\mathrm{E}$ and selenium (52.93 \pm 0.65$)$ and selenium ( 52.36 \pm 0.51) supplemented rabbits. The unsupplemented control $\left(\mathrm{T}_{1}\right)$ rabbits registered the lowest dressing percentage $(52.27 \pm 1.40)$.

The statistical analysis of mean dressing percentage revealed significant $(\mathrm{P}<0.05)$ difference between the treatment groups.

\section{Cut up parts}

The mean cut up parts (Neck, foreleg, chest and back, loin and flank, hind leg and pelt) of Soviet Chinchilla rabbits supplemented with various antioxidants are furnished in Table 2.

The mean cut up parts of Soviet Chinchilla rabbits supplemented with various antioxidants showed no significant difference between the treatment groups.

\section{Offal yield}

The mean weight of offals (g) of Soviet Chinchilla rabbits are given in Table 2 Weight of the offals are in the range of average values and showed no significant difference between the treatment groups.

\section{Pre-slaughter weight}

The mean pre-slaughter weight of the rabbits supplemented with vitamin $\mathrm{C}, \mathrm{E}$ and selenium either alone $\left(\mathrm{T}_{2}\right.$ to $\left.\mathrm{T}_{4}\right)$ or in combination $\left(\mathrm{T}_{5}\right.$ to $\mathrm{T}_{8}$ ) showed significantly $(\mathrm{P}<0.05)$ higher preslaughter weight (Table 1) as compared to control $\left(\mathrm{T}_{1}\right)$. The highest mean pre-slaughter weight was recorded in the vitamin $\mathrm{C}, \mathrm{E}$ and selenium supplemented $\left(\mathrm{T}_{8}\right)$ rabbits $(2230.16$ g) as compared to control (2019.33 g) rabbits $\left(\mathrm{T}_{1}\right)$. The mean pre-slaughter weight of the rabbits supplemented with vitamin $C$, vitamin $E$ and selenium either alone $\left(T_{2}\right.$ to $\left.T_{4}\right)$ or in combinations $\left(T_{5}\right.$ to $\left.T_{8}\right)$ showed significantly
$(\mathrm{P}<0.05)$ higher pre-slaughter weight as compared to control $\left(\mathrm{T}_{1}\right)$. The highest preslaughter weight was recorded in the vitamin $\mathrm{C}$, vitamin $\mathrm{E}$ and selenium supplemented $\left(\mathrm{T}_{8}\right)$ rabbits (2230.16g) as compared to control (2019.33g) rabbits (T1). In contrast to above findings, Szendro et al., (2012) observed no significant difference in the pre-slaughter weight of rabbits supplemented with vitamin $\mathrm{E}$ (240 mg per $\mathrm{kg}$ diet) and selenium (0.46 mg per kg diet) as compared to control diets.

\section{Hot carcass}

Compared to control group, the rabbits supplemented with antioxidants (Vitamin C, vitamin $\mathrm{E}$ and selenium) during heat stress period showed higher $(\mathrm{P}<0.01)$ hot carcass weight. The lower mean hot carcass weight observed in the control rabbit might be due to the effect of heat stress leads to poor feed conversion ratio, lower weight gain, lower live weight resulted in lower hot carcass weight as compared to antioxidants supplemented rabbits. The highest hot carcass weight was recorded in the vitamin $\mathrm{C}, \mathrm{E}$ and selenium supplemented (1244.66 g) rabbits compared to control (1055.66 g). The highest hot carcass weight observed in vitamin $\mathrm{C}, \mathrm{E}$ and selenium supplemented groups could be attributable to the heat ameliorating effect of vitamin $\mathrm{C}$, free radicals scavenging antioxidant effect of vitamin $\mathrm{E}$ and selenium in heat stressed rabbits.

In close accordance with above finding Selim et al., (2008) and Okachi and Ani (2016) reported higher carcass weight in vitamin $\mathrm{C}$ and $\mathrm{E}$ supplemented rabbits compared to control. Whereas Szendro et al., (2012), Abd El -Khalek et al., (2013), Ebeid et al., (2013) and Abdel-Khalek et al., (2016) found no significant difference in the hot carcass weight in rabbits supplemented with varying levels of vitamin $\mathrm{E}$ and selenium either alone or in combination as compared to control. 
Table.1 Mean $( \pm$ SE) carcass characteristics $(\mathrm{g})$ of rabbits supplemented with various antioxidants

\begin{tabular}{|c|c|c|c|c|c|c|c|c|}
\hline Treatment & $\begin{array}{c}\text { Pre - } \\
\text { slaughter } \\
\text { weight }\end{array}$ & $\begin{array}{c}\text { Hot carcass } \\
\text { weight }\end{array}$ & $\begin{array}{l}\text { Dressing } \\
\text { percentage }\end{array}$ & Neck & Foreleg & $\begin{array}{c}\text { Chest } \\
\text { and Back }\end{array}$ & $\begin{array}{l}\text { Loin and } \\
\text { Flank }\end{array}$ & Hind Leg \\
\hline $\mathrm{T}_{1}$ Basal feed & $\begin{array}{l}2019.33^{\mathrm{a}} \pm \\
\quad 38.03\end{array}$ & $\begin{array}{l}1055.66^{\mathrm{a}} \pm \\
20.54\end{array}$ & $\begin{array}{c}52.27^{\mathrm{a}} \pm \\
1.40\end{array}$ & $\begin{array}{c}45.33 \pm \\
1.80\end{array}$ & $\begin{array}{c}183.33 \pm \\
0.95\end{array}$ & $\begin{array}{c}283.16 \pm \\
0.87\end{array}$ & $\begin{array}{c}285.00 \pm \\
0.36\end{array}$ & $\begin{array}{c}382.83 \pm \\
2.06\end{array}$ \\
\hline $\mathrm{T}_{2}$ Vitamin $\mathrm{C}$ & $\begin{array}{c}2138.00^{a b c} \pm \\
22.53\end{array}$ & $\begin{array}{c}1174.33^{\mathrm{bcd}} \\
\pm 24.57\end{array}$ & $\begin{array}{c}54.91^{\mathrm{ab}} \pm \\
0.81\end{array}$ & $\begin{array}{c}42.33 \pm \\
4.58\end{array}$ & $\begin{array}{c}184.50 \pm \\
0.42\end{array}$ & $\begin{array}{c}284.50 \pm \\
0.61\end{array}$ & $\begin{array}{c}285.50 \pm \\
0.76\end{array}$ & $\begin{array}{c}386.67 \pm \\
2.63\end{array}$ \\
\hline $\mathrm{T}_{3}$ Vitamin $\mathrm{E}$ & $\begin{array}{c}2151.50^{b c} \\
26.55\end{array}$ & $\begin{array}{c}1141.66^{\mathrm{abc}} \\
27.35\end{array}$ & $\begin{array}{c}53.03^{\mathrm{a}} \pm \\
0.60\end{array}$ & $\begin{array}{c}47.50 \pm \\
3.26\end{array}$ & $\begin{array}{c}182.33 \pm \\
1.05\end{array}$ & $\begin{array}{c}284.00 \pm \\
0.93\end{array}$ & $\begin{array}{c}286.16 \pm \\
0.70\end{array}$ & $\begin{array}{c}384.50 \pm \\
0.99\end{array}$ \\
\hline $\mathrm{T}_{4}$ Selenium & $\begin{array}{c}2142.66^{\mathrm{abc}} \pm \\
28.36\end{array}$ & $\begin{array}{c}1121.66^{\mathrm{abc}} \pm \\
15.76\end{array}$ & $\begin{array}{c}52.36^{\mathrm{a}} \pm \\
0.51\end{array}$ & $\begin{array}{c}47.50 \pm \\
6.09\end{array}$ & $\begin{array}{c}184.00 \pm \\
0.36\end{array}$ & $\begin{array}{c}284.83 \pm \\
0.47\end{array}$ & $\begin{array}{c}285.50 \pm \\
0.71\end{array}$ & $\begin{array}{c}383.33 \pm \\
0.95\end{array}$ \\
\hline $\begin{array}{l}\mathrm{T}_{5} \text { Vitamin } \mathrm{C} \text { and } \\
\mathrm{E}\end{array}$ & $\begin{array}{c}2155.00^{\mathrm{bc}} \pm \\
44.05\end{array}$ & $\begin{array}{c}1201.33^{\mathrm{cd}} \pm \\
18.29\end{array}$ & $\begin{array}{c}55.80^{c} \pm \\
0.67\end{array}$ & $\begin{array}{c}44.66 \pm \\
5.16\end{array}$ & $\begin{array}{c}183.33 \pm \\
0.33\end{array}$ & $\begin{array}{c}284.50 \pm \\
0.56\end{array}$ & $\begin{array}{c}285.33 \pm \\
0.33\end{array}$ & $\begin{array}{c}384.17 \pm \\
1.45\end{array}$ \\
\hline $\begin{array}{l}\mathrm{T}_{6} \text { Vitamin } \mathrm{C} \text { and } \\
\text { selenium }\end{array}$ & $\begin{array}{c}2140.83^{\mathrm{abc}} \pm \\
52.54\end{array}$ & $\begin{array}{c}1175.16^{\mathrm{bcd}} \\
\pm 45.90\end{array}$ & $\begin{array}{c}54.82^{\mathrm{ab}} \pm \\
1.01\end{array}$ & $\begin{array}{c}47.00 \pm \\
1.69\end{array}$ & $\begin{array}{c}183.50 \pm \\
0.67\end{array}$ & $\begin{array}{c}284.50 \pm \\
0.56\end{array}$ & $\begin{array}{c}285.33 \pm \\
1.11\end{array}$ & $\begin{array}{c}384.17 \pm \\
0.75\end{array}$ \\
\hline $\begin{array}{l}\mathrm{T}_{7} \text { Vitamin } \mathrm{E} \text { and } \\
\text { selenium }\end{array}$ & $\begin{array}{c}2083.50^{\mathrm{ab}} \pm \\
21.88\end{array}$ & $\begin{array}{c}1103.33^{\mathrm{ab}} \pm \\
24.38\end{array}$ & $\begin{array}{c}52.93^{\mathrm{a}} \pm \\
0.65\end{array}$ & $\begin{array}{l}48.66 \pm \\
2.53\end{array}$ & $\begin{array}{c}184.00 \pm \\
0.57\end{array}$ & $\begin{array}{c}285.00 \pm \\
0.36\end{array}$ & $\begin{array}{c}285.00 \pm \\
0.68\end{array}$ & $\begin{array}{c}383.50 \pm \\
1.57\end{array}$ \\
\hline $\begin{array}{l}\mathrm{T}_{8} \text { Vitamin } \mathrm{C}, \mathrm{E} \\
\text { and selenium }\end{array}$ & $\begin{array}{l}2230.16^{\mathrm{c}} \pm \\
59.88\end{array}$ & $\begin{array}{c}1244.66^{\mathrm{d}} \pm \\
39.25\end{array}$ & $\begin{array}{c}55.80^{c} \pm \\
0.71\end{array}$ & $\begin{array}{c}49.66 \pm \\
2.20\end{array}$ & $\begin{array}{c}183.50 \pm \\
0.88\end{array}$ & $\begin{array}{c}283.00 \pm \\
0.68\end{array}$ & $\begin{array}{c}285.00 \pm \\
0.51\end{array}$ & $\begin{array}{c}383.00 \pm \\
2.08\end{array}$ \\
\hline P-value & $0.037 *$ & $0.02 * *$ & 0.018* & $0.635^{\mathrm{NS}}$ & $0.576^{\mathrm{NS}}$ & $0.242^{\mathrm{NS}}$ & $0.939^{\mathrm{NS}}$ & $0.952^{\mathrm{NS}}$ \\
\hline
\end{tabular}

NS - Non significant

* Significant $(\mathrm{P}<0.05)$, ** Highly significant $(\mathrm{P}<0.01)$,

Means bearing the same superscript in a column do not differ significantly. 
Table.2 Mean ( \pm SE) weight of offals $(g)$ of rabbits supplemented with various antioxidants

\begin{tabular}{|c|c|c|c|c|c|c|c|c|}
\hline Treatment & Head & $\begin{array}{l}\text { Lung and } \\
\text { Heart }\end{array}$ & G.I tract & Liver & Kidney & $\begin{array}{l}\text { Paw and } \\
\text { Tail }\end{array}$ & Pelt & Blood \\
\hline $\mathrm{T}_{1}$ Basal feed & $\begin{array}{c}209.33 \pm \\
7.68\end{array}$ & $\begin{array}{l}19.66 \pm \\
2.03\end{array}$ & $\begin{array}{c}398.66 \pm \\
24.02\end{array}$ & $\begin{array}{l}55.00 \pm \\
2.67\end{array}$ & $\begin{array}{c}14.33 \pm \\
1.30\end{array}$ & $\begin{array}{c}100.66 \pm \\
9.08\end{array}$ & $\begin{array}{l}259.33 \pm \\
23.25\end{array}$ & $\begin{array}{l}57.00 \pm \\
2.78\end{array}$ \\
\hline $\mathrm{T}_{2}$ Vitamin $\mathrm{C}$ & $\begin{array}{c}224.00 \pm \\
10.79\end{array}$ & $\begin{array}{c}18.33 \pm \\
1.74\end{array}$ & $\begin{array}{c}367.66 \pm \\
13.63\end{array}$ & $\begin{array}{c}57.00 \pm \\
1.84\end{array}$ & $\begin{array}{c}14.66 \pm \\
1.11\end{array}$ & $\begin{array}{c}96.66 \pm \\
15.21\end{array}$ & $\begin{array}{c}269.67 \pm \\
18.61\end{array}$ & $\begin{array}{l}56.83 \pm \\
1.85\end{array}$ \\
\hline $\mathrm{T}_{3}$ Vitamin $\mathrm{E}$ & $\begin{array}{c}225.33 \pm \\
9.54\end{array}$ & $\begin{array}{l}20.00 \pm \\
1.36\end{array}$ & $\begin{array}{l}323.00 \pm \\
58.39\end{array}$ & $\begin{array}{c}46.00 \pm \\
6.61\end{array}$ & $\begin{array}{c}12.66 \pm \\
0.66\end{array}$ & $\begin{array}{c}107.66 \pm \\
11.97\end{array}$ & $\begin{array}{c}294.00 \pm \\
17.08\end{array}$ & $\begin{array}{c}57.83 \pm \\
2.00\end{array}$ \\
\hline $\mathrm{T}_{4}$ Selenium & $\begin{array}{c}222.33 \pm \\
13.57\end{array}$ & $\begin{array}{c}22.33 \pm \\
1.49\end{array}$ & $\begin{array}{c}401.66 \pm \\
25.32\end{array}$ & $\begin{array}{c}61.00 \pm \\
6.98\end{array}$ & $\begin{array}{c}14.66 \pm \\
1.11\end{array}$ & $\begin{array}{c}101.83 \pm \\
18.86\end{array}$ & $\begin{array}{c}279.67 \pm \\
22.55\end{array}$ & $\begin{array}{c}58.50 \pm \\
2.07\end{array}$ \\
\hline $\begin{array}{l}\mathrm{T}_{5} \text { Vitamin } \mathrm{C} \text { and } \\
\mathrm{E}\end{array}$ & $\begin{array}{c}208.33 \pm \\
7.52\end{array}$ & $\begin{array}{l}20.66 \pm \\
1.42\end{array}$ & $\begin{array}{c}364.33 \pm \\
12.23\end{array}$ & $\begin{array}{l}54.33 \pm \\
2.15\end{array}$ & $\begin{array}{c}14.33 \pm \\
0.802\end{array}$ & $\begin{array}{c}88.33 \pm \\
15.22\end{array}$ & $\begin{array}{c}262.33 \pm \\
20.84\end{array}$ & $\begin{array}{c}53.66 \pm \\
0.33\end{array}$ \\
\hline $\begin{array}{l}\mathrm{T}_{6} \text { Vitamin } \mathrm{C} \\
\text { and selenium }\end{array}$ & $\begin{array}{c}216.00 \pm \\
10.49\end{array}$ & $\begin{array}{c}21.33 \pm \\
1.42\end{array}$ & $\begin{array}{c}389.00 \pm \\
18.88\end{array}$ & $\begin{array}{l}59.33 \pm \\
7.03\end{array}$ & $\begin{array}{c}13.00 \pm \\
1.12\end{array}$ & $\begin{array}{c}98.66 \pm \\
10.74\end{array}$ & $\begin{array}{c}272.67 \pm \\
23.40\end{array}$ & $\begin{array}{l}55.66 \pm \\
1.47\end{array}$ \\
\hline $\begin{array}{l}\mathrm{T}_{7} \text { Vitamin } \mathrm{E} \text { and } \\
\text { selenium }\end{array}$ & $\begin{array}{c}215.00 \pm \\
14.21\end{array}$ & $\begin{array}{c}19.33 \pm \\
1.97\end{array}$ & $\begin{array}{c}394.33 \pm \\
27.78\end{array}$ & $\begin{array}{c}57.00 \pm \\
4.52\end{array}$ & $\begin{array}{c}15.33 \pm \\
1.11\end{array}$ & $\begin{array}{c}94.00 \pm \\
10.75\end{array}$ & $\begin{array}{c}266.00 \pm \\
10.60\end{array}$ & $\begin{array}{l}58.50 \pm \\
2.87\end{array}$ \\
\hline $\begin{array}{l}\mathrm{T}_{8} \text { Vitamin } \mathrm{C}, \mathrm{E} \\
\text { and selenium }\end{array}$ & $\begin{array}{c}206.00 \pm \\
7.47\end{array}$ & $\begin{array}{c}22.33 \pm \\
1.40\end{array}$ & $\begin{array}{c}360.00 \pm \\
15.41\end{array}$ & $\begin{array}{c}55.66 \pm \\
5.40\end{array}$ & $\begin{array}{c}14.66 \pm \\
2.34\end{array}$ & $\begin{array}{c}92.66 \pm \\
11.01\end{array}$ & $\begin{array}{c}260.00 \pm \\
30.81\end{array}$ & $\begin{array}{c}53.00 \pm \\
1.93\end{array}$ \\
\hline P-value & $0.824^{\mathrm{NS}}$ & $0.567^{\mathrm{NS}}$ & $0.522^{\mathrm{NS}}$ & $0.608^{\mathrm{NS}}$ & $0.833^{\mathrm{NS}}$ & $0.982^{\mathrm{NS}}$ & $0.805^{\mathrm{NS}}$ & $0.414^{\mathrm{NS}}$ \\
\hline
\end{tabular}

NS - Non significant. 


\section{Dressing percentage}

The mean dressing percentage of the rabbits supplemented with vitamin $C$, vitamin $E$ and selenium either alone $\left(T_{2}\right.$ to $\left.T_{4}\right)$ or in combinations $\left(\mathrm{T}_{5}\right.$ to $\left.\mathrm{T}_{8}\right)$ had significantly $(\mathrm{P}<$ 0.05 ) higher dressing percentage as compared to control $\left(T_{1}\right)$ rabbits. The highest dressing percentage $(55.80$ per cent) was recorded in the vitamin $C$, vitamin $E$ and selenium $\left(T_{8}\right)$ and vitamin $\mathrm{C}$ and $\mathrm{E}\left(\mathrm{T}_{5}\right)$ supplemented rabbits as compared to unsupplemented control (52.27 per cent) rabbits.

In agreement with above findings, Okach and Ani (2016) also observed higher dressing percentage in all the groups of rabbits supplemented with dose rate of $200 \mathrm{mg}$ or $400 \mathrm{mg}$ per $\mathrm{kg}$ diet (vitamin $\mathrm{C}$ or vitamin $\mathrm{E}$ either alone or combination) as compared to unsupplemented control rabbits. Likewise, Selim et al., (2008) while comparing different levels of vitamin C (200 and $400 \mathrm{mg}$ per $\mathrm{kg}$ diet) and vitamin E(40 and $80 \mathrm{mg}$ per $\mathrm{kg}$ diet $)$ either alone or in combination reported significant difference in dressing percentage of the carcass whereas El- Medany et al., (2012) reported higher dressing percentage (53.4 per cent) at the highest level $(120 \mathrm{mg}$ per kg diet) of vitamin E supplemented rabbit as compared to other levels (40 or $80 \mathrm{mg}$ per $\mathrm{kg}$ diet) of vitamin $\mathrm{E}$. On the contrary, many workers while supplementing vitamin $\mathrm{C}$ or different levels of selenium (Selim et al., 2004 and Abdel- khalek et al., 2013), or combination of vitamin $\mathrm{E}$ and selenium (Szendro et al., 2012); Ebeid et al., 2013; and Abdel- Khalek et al., 2016) found no significant difference in the dressing percentage between the antioxidant supplemented and control group of rabbits.

\section{Cut up parts}

Compared to unsupplemented control rabbits $\left(\mathrm{T}_{1}\right)$ the mean cut up parts (Neck, foreleg, chest and back, loin and flank and hind leg) of Soviet Chinchilla rabbits supplemented with vitamin $C$, vitamin $E$ and selenium either alone or in combination during the period of heat stress showed no significant difference. The mean weight of Neck (49.66 g), foreleg $(183.50 \mathrm{~g})$, chest and back (283.00 g), loin and flank $(285.00 \mathrm{~g})$ and hind leg (383.00 g)of all the treatment groups $\left(T_{1}\right.$ to $\left.T_{8}\right)$ were in the average values of Soviet Chinchilla rabbits.

\section{Offal yield}

The mean weight of offals of Soviet Chinchilla rabbits supplemented with vitamin $\mathrm{C}$, vitamin $\mathrm{E}$ and selenium either alone or in combination during the period of heat stress showed no significant difference as compared to unsupplemented control rabbits. The mean weights of 206.00, 22.33, 360.00, 55.66, $14.66,92.66,260.00,53.00 \mathrm{~g}$ ) respectively.

Similar to the above findings, Ebeid et al., 2013 also reported significant difference in head weight, heart weight, liver weight, lung weight and kidney weight of rabbits supplemented with vitamin $\mathrm{E}$ and selenium either alone or in combination as compared to control. Likewise, many workers reported no significant difference in the edible and inedible offal weights of rabbits supplemented with vitamin C (Selim et al., 2004), vitamin C and E (Selim et al.,2008), vitamin E (ElMedany et al., 2012) and selenium (Abdel khalek et al., 2013) and vitamin E and selenium (Szendro et al., 2012 and AbdelKhalek et al., 2016) as compared to control rabbits.

\section{Summary}

In terms of live body weight, dressing percentage of vitamin C, E and Selenium supplementation showed better performance. Slaughter studies revealed that rabbit fed with 
vitamin $\mathrm{C}$, vitamin $\mathrm{E}$ and selenium supplementation had significantly by $(\mathrm{P}<$ $0.05)$ higher on pre-slaughter weight (2230.16 \pm 59.88), dressing percentage (55.80 per cent); and recorded highly significant difference $(\mathrm{P}<0.01)$ in hot carcass weight when compared to other treatment groups. However, there was no significant difference observed in the offal yields.

\section{Acknowledgement}

The authors are thankful to the Tamil Nadu Veterinary and Animal Sciences University for providing all the facilities to perform the study.

\section{References}

Abd El - Khalek, A. M., A.AyatRagab, A.I.Abd El - Lateif, M.R. Amira, M.Kout El- Kloub, El. Moustafa and A.R. ElBetagy, 2013. Effect of dietary selenium levels on growth performance and glutathione peroxidase activity of rabbits under summer season conditions. In: Proceeding of the $4^{\text {th }}$ Scientific Conference of Animal Production Research Institute, pp., 364-369.

Abdel- Khalek A.M., A.S. Soliman., T.S. Rabie and M.K. Greash, 2016. Effect of dietary supplementation with potential antioxidants and tannins on growing rabbit performance during summer season. Proceedings $11^{\text {th }}$ World Rabbit Congress, pp. 15-18.

Basavaraj M., V. Nagabhushana, N, Prakash, M.M. Appannavar, P. Wagmare and S. Mallikarjunappa, 2011. Effect of dietary supplementation of curcuma longa on the biochemical profile and meat characteristics of broiler rabbits under summer stress. Vet. World.,4(1):15-18.

Ebeid, T. A., H.S. Zeweil, M.M. Basyony,
W.M. Dosoky and H. Badry, 2013. Fortification of rabbits diets with vitamin E or Selenium affects growth performance, lipid peroxidation, oxidative status and immune response in growing rabbits. Livestock Science., 155: 323-331.

El-Medany Sh. A., A.M. Abdel Khalek,S.A. Gad Alla, F. GihanShaaban, M.A. Abo- Warden, M. ArafaMervat, A.A. Azoz and Z. MeshrekySamia, 2012. Interaction between supplemental vitamin $\mathrm{E}$ and endogenous antioxidant enzymes of different rabbit genetic resources: 1 -Effect on performance during summer season. In: Proceedings $10^{\text {th }}$ world rabbit congress, pp. 563-567.

Okachi V. C. W and A.O. Ani, 2016. Effects of dietary inclusion of vitamin $\mathrm{C}$ and $\mathrm{E}$ on nutrient digestibility, haematological and carcass characteristics of Rabbits in a hot humid tropical environment. International journal of agricultural research and Review.,4(3): 494-503.

Ramayyan, G.N. (1977) M.V.Sc. Thesis, Tamil Nadu Agricultural University, Chennai.

Selim A.D., A.Z. Soliman and A.M. Abdelkhalek, 2004. Effect of drinking water temperature and some dietary feed additives on performance of heat stressed rabbits. Proceedings- $8^{\text {th }}$ World Rabbit Congress, pp. 7-10.

Selim, N. A., A.M. Abdel - Khalek, S.A. Nada and A. EL- MedanySh, 2008. Response of growing rabbits to dietary antioxidant vitamins E and C. I. Effect on performance. $9^{\text {th }}$ World Rabbit congress, pp: 803-807.

Snedecor, G.W and W.G. Cocharan, 1994. Statistical methods. $8^{\text {th }}$ Edition, Iowa state Press, Ames, Iowa, USA.

Subramaniam Mohana Devi, Vellingiri Balachandar, Sang In Lee and In Ho 
Kim, 2014. An outline of meat consumption in the Indian population. Korean J. Food Sci. Anim. Resour., 34(4): 507-515.

Szendro, Zs., Zs Gerencser, Szabo A., Febel H., Szin M., Radnai I., Dalle Zotte A.,

Matics Zs.2012.Effect of supplementation of linseed oil, vitamin $\mathrm{E}$ and selenium in diet for growing rabbits on productive and carcass traits. Proceedings $10^{\text {th }}$ World Rabbit Congress, 3 - 6, pp. 881-885.

\section{How to cite this article:}

Dinesh kumar, S., Anandha Prakash Singh, D., Natarajan, A. and Sivakumar, K. 2018. Carcass Characteristics of Soviet Chinchilla Rabbits Supplemented with Vitamin C, E and Selenium during the Period of Heat Stress. Int.J.Curr.Microbiol.App.Sci. 7(08): 1962-1969. doi: https://doi.org/10.20546/ijcmas.2018.708.226 